\title{
Diagnosis and treatment of enthesitis-related arthritis
}

This article was published in the following Dove Press journal:

Adolescent Health, Medicine and Therapeutics

4 June 2012

Number of times this article has been viewed

\section{Pamela F Weiss \\ Division of Rheumatology and Center for Pediatric Clinical Effectiveness, The Children's Hospital of Philadelphia, Departments of Pediatrics and Center for Clinical Epidemiology and Biostatistics, University of Pennsylvania School of Medicine, Philadelphia, PA, USA}

Correspondence: Pamela F Weiss Room 1526, North Campus, Division of Rheumatology, The Children's Hospital of Philadelphia, 3535 Market Street, Philadelphia, PA 19104

$\mathrm{Tel}+\mathrm{I} 2674262303$

Fax + I 2I 55900380

Email weisspa@email.chop.edu
Abstract: Juvenile idiopathic arthritis (JIA) is a chronic, inflammatory disease of unknown etiology. The enthesitis-related arthritis (ERA) JIA category describes a clinically heterogeneous group of children including some who have predominately enthesitis, enthesitis and arthritis, juvenile ankylosing spondylitis, or inflammatory bowel disease-associated arthropathy. ERA accounts for 10\%-20\% of JIA. Common clinical manifestations of ERA include arthritis, enthesitis, and acute anterior uveitis. Axial disease is also common in children with established ERA. Treatment regimens for ERA, many of them based on adults with rheumatoid arthritis and ankylosing spondylitis, include the use of nonsteroidal anti-inflammatory drugs, diseasemodifying antirheumatic drugs, and biologic agents either individually or in combination.

Keywords: juvenile arthritis, enthesitis, sacroillitis, epidemiology, therapy

\section{Introduction}

Juvenile idiopathic arthritis (JIA) is a chronic, inflammatory disease of unknown etiology. It is the most common pediatric rheumatic illness with an estimated annual incidence of approximately three to six cases per 100,000 children. ${ }^{1}$ The term "JIA" describes a clinically heterogeneous group of diseases characterized by arthritis that begins before the age of 16 years, involves one or more joints, and lasts at least 6 weeks. Distinct clinical features characterize each of the JIA categories during the first 6 months of the disease. The enthesitis-related arthritis (ERA) JIA category describes a clinically heterogeneous group of children including some who have predominately enthesitis, enthesitis and arthritis, juvenile ankylosing spondylitis, or inflammatory bowel disease-associated arthropathy. ERA accounts for $10 \%-20 \%$ of JIA $^{2-4}$ and mostly occurs in late childhood or adolescence with a peak age of onset of 12 years. ${ }^{5,6}$ Males are affected more often than females, accounting for approximately $60 \%$ of cases. ${ }^{6}$ Approximately $45 \%$ of children are HLA-B27 positive, and $20 \%$ have a family history of HLA-B27-associated disease, such as reactive arthritis, ankylosing spondylitis, or inflammatory bowel disease with sacroiliitis. ${ }^{6}$ Antinuclear antibodies and rheumatoid factor are characteristically negative.

\section{Diagnosis of ERA}

\section{Clinical characteristics of ERA}

ERA is defined by the International League Against Rheumatism as arthritis and enthesitis of at least 6 weeks' duration in a child younger than 16 years, or arthritis or enthesitis plus two of the following: sacroiliac tenderness or inflammatory spinal 
pain, HLA-B27 positivity, onset of arthritis in a male older than 6 years, and family history of HLA-B27-associated disease. ${ }^{7}$ Common clinical manifestations of ERA include arthritis, enthesitis, and acute anterior uveitis. In the first 6 months of disease, oligoarticular (in four or fewer joints) disease is most common. The most commonly affected joints at diagnosis are the sacroiliacs, knees, ankles, and hips. ${ }^{6}$ The small joints of the feet and toes are also commonly involved. ${ }^{8}$ Midfoot joint inflammation, or tarsitis, is highly suggestive of the diagnosis.

Axial disease is common in children with established ERA. By 2, 4, and 5 years after disease onset, as many as $15 \%, 53 \%$, and $92 \%$, respectively, of children with juvenile spondyloarthropathy (SpA), a condition that encompasses most children with ERA, develop symptomatic sacroiliitis. ${ }^{9}$ Up to $35 \%-48 \%$ of children with ERA have clinical or radiographic evidence of sacroiliitis (Figure 1A). ${ }^{6}, 10-12$ Untreated sacroiliitis may progress to spondylitis, which is a condition characterized by radiographic findings of corner lesions (Figure 1B), erosions, syndesmophytes, diskitis, and ankylosis or fusion of the axial joints. Once sacroiliitis has developed and changes are visible on radiographs, treatment can be problematic. Sacroiliitis may not respond to medications commonly used as first-line agents for JIA, such as nonsteroidal anti-inflammatory drugs (NSAIDs) or diseasemodifying antirheumatic drugs (DMARDs), and the disease may continue to progress along the axial skeleton. A subset of children with sacroiliitis will progress to spondylitis as adults, which is characterized by back pain, stiffness, and eventual fusion of the vertebra.

Enthesitis is a distinct pathologic feature of ERA as well as adult SpA, including ankylosing spondylitis and psoriatic arthritis. Enthesitis is defined as inflammation of an enthesis, which is a site where a tendon, ligament, or joint capsule attaches to bone (Figure 1C). Enthesitis in ERA is often symmetric and largely affects the lower limbs. ${ }^{12}$ In one series, children with ERA had at least one documented tender enthesis at $47 \%$ of visits and more than three tender entheses at $18 \%$ of visits. ${ }^{6}$ The most commonly affected entheses were the patellar ligament insertion at the inferior pole of the patella, plantar fascial insertion at the calcaneus, and the Achilles tendon insertion at the calcaneus. ${ }^{6}$ In another cross-sectional study that used whole-body magnetic resonance imaging (MRI) to detect enthesitis, the hip extensor insertion at the greater trochanter was the most common site involved. ${ }^{12}$ Late manifestations of enthesitis in adults include osteopenia, bone cortex irregularity, erosions, soft tissue calcifications, and new bone formation at the bone
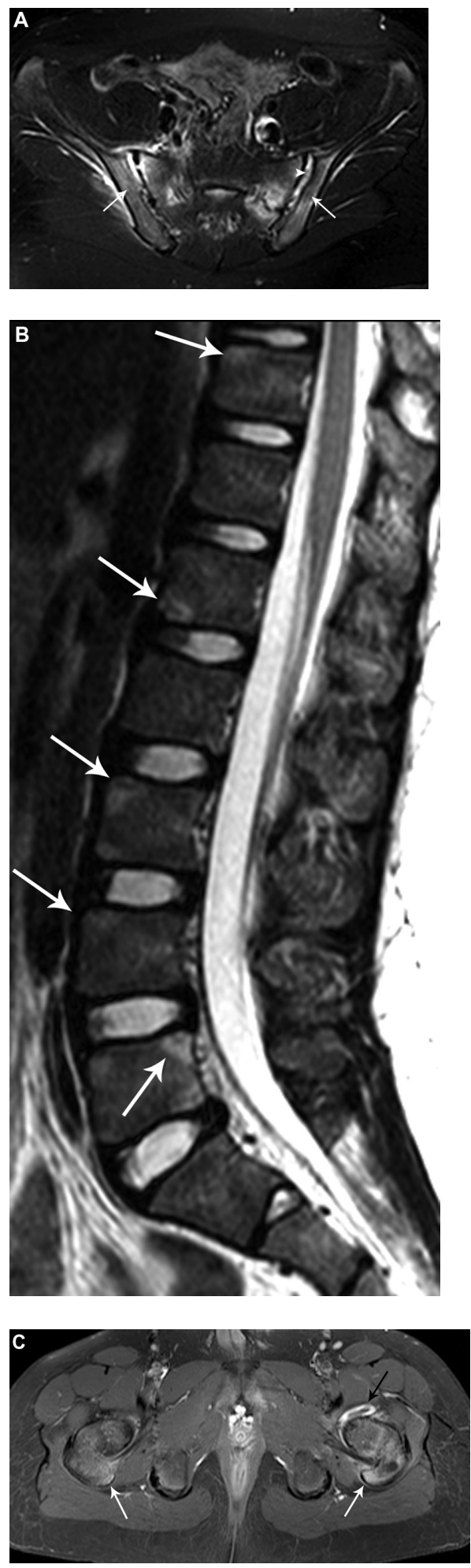

Figure I Radiographic findings of spinal and sacroiliac involvement. (A) Axial T2weighted image of the sacroiliac joints demonstrate fluid within both sacroiliac joints with widening of the left sacroiliac joint. There is bone marrow edema within the sacral ala and adjacent iliac wings (arrows). (B) Sagittal T2-weighted image of the lumbar spine demonstrates triangular-shaped regions of edema along the corners of the vertebral bodies (arrows) consistent with magnetic resonance corner lesions. (C) Axial TI-weighted postcontrast image shows left hip synovitis (black arrow). There is enhancing edema within both greater trochanters and at the hip flexor entheses (white arrows) with mild surrounding soft tissue inflammatory changes. Courtesy of Dr Nancy Chauvin, The Children's Hospital of Philadelphia, Philadelphia, PA. 
insertion sites. ${ }^{13,14}$ Enthesitis may not parallel the activity of, or respond as well to therapy as, the arthritis. ${ }^{15}$

The uveitis associated with ERA is characterized by redness, pain, and photophobia (Figure 2). It is typically unilateral and often recurrent. In one series, $10 \%$ of children developed acute uveitis in the first 6 months of disease. ${ }^{6}$ Another series reported that $27 \%$ of children developed acute anterior uveitis over the course of disease. ${ }^{16}$ Persistent anterior uveitis can lead to short and long-term complications including iris scarring, corneal calcium deposition, glaucoma, cataracts, macular edema, and visual loss.

\section{Laboratory testing}

There are no diagnostic laboratory tests for ERA. The selection of specific laboratories should be guided by the history and physical examination. A complete blood count (CBC) with differential and inflammatory markers should be part of the initial evaluation of any child with joint swelling. HLAB27 is strongly associated with transient reactive arthritis, inflammatory bowel disease, and ERA. Antinuclear antibodies and rheumatoid factor are typically negative.

\section{Methods to detect enthesitis}

Enthesitis in children is typically diagnosed by clinical findings including localized pain, tenderness, and swelling. The findings at certain entheses, however, are nonspecific and can also be found in normal children, ${ }^{17}$ along with overuse injuries, apophysitis, and fibromyalgia. Multiple instruments have been used in adults to assess the extent and severity of enthesitis in adults, including the Mander Index, ${ }^{18}$ a modified Mander Index, ${ }^{19}$ the Spondyloarthritis Research Consortium of Canada Enthesitis Index, ${ }^{20}$ the Maastricht Ankylosing

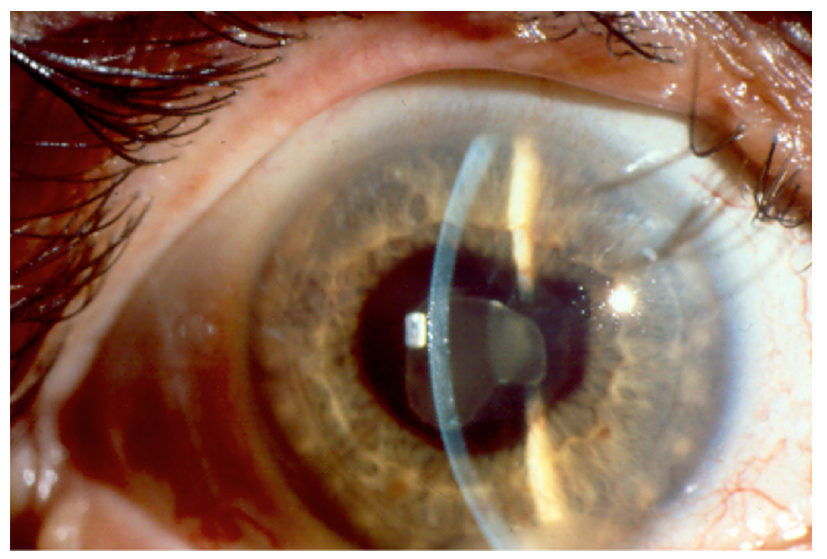

Figure 2 Enthesitis-related arthritis-associated acute anterior uveitis. Recurrent HLAB27-associated anterior uveitis with hypopyon and extensive posterior synechiae. Courtesy of Dr JP Dunn, The Wilmer Eye Institute, The Johns Hopkins School of Medicine, Baltimore, MD.
Spondylitis Enthesitis Score, ${ }^{20,21}$ the Leeds Enthesitis Index, ${ }^{22}$ and the Major Enthesitis Index. ${ }^{23}$ The entheses examined with the Spondyloarthritis Research Consortium of Canada, Maastricht Ankylosing Spondylitis Enthesitis Score, Leeds Enthesitis Index, and Major Enthesitis Index are listed in Table 1. A standardized enthesitis index for pediatric patients has not yet been developed. In practice, many pediatric rheumatologists examine the lower extremity entheses by applying pressure on each enthesis with the dominant thumb until the nailbed blanches.

Imaging is not routinely used in children for detection of enthesitis. However, in adult SpA, ultrasonography with Doppler (USD) and MRI are helpful to distinguish inflammatory enthesitis from other noninflammatory conditions such as overuse injuries, apophysitis, and fibromyalgia. ${ }^{24-26}$ The positive and negative predictive values of physical examination for enthesitis at the Achilles tendon in adults, using USD as the gold standard, are 0.55 and 0.73 , respectively. ${ }^{24}$ USD and physical examination may be complimentary, as several studies have shown enthesitis by USD in clinically normal sites. ${ }^{27-29}$ The most common ultrasound abnormalities in adult entheses are enthesophytes, calcifications, tendon thickening, and hypoechogenicity. ${ }^{27}$ Imaging with whole-body MRI in children with ERA has suggested that inflammatory enthesitis is overestimated in children by physical examination, ${ }^{12}$ emphasizing that imaging may be an important tool for assessment of enthesitis and for monitoring treatment response.

\section{Methods to detect sacroiliitis}

International League Against Rheumatism criteria define sacroiliitis in children clinically as the presence of tenderness on direct compression over the sacroiliac joint. ${ }^{7}$ Other physical examination findings that may indicate sacroiliitis are decreased lumbar flexion or a positive Patrick's test (a maneuver that causes pain in the contralateral sacroiliac joint with downward pressure on the knee when it is flexed and the hip is externally rotated, flexed, and abducted). Inflammatory back pain, which is defined as lower back pain that starts insidiously, improves with exercise, and is associated with more than 30 minutes of morning stiffness or alternating buttock pain, may also herald sacroiliitis. ${ }^{30,31}$ In one retrospective study, eleven of 53 (21\%) children with radiographic findings of sacroiliitis did not have any physical examination abnormalities or a history of inflammatory back pain. ${ }^{32}$ The positive and negative predictive values of sacroiliac joint compression in the detection of sacroiliitis in children are unknown. 
Table I Entheses included in adult enthesitis indices

\begin{tabular}{|c|c|c|c|c|}
\hline & $\begin{array}{l}\text { Spondyloarthritis research } \\
\text { consortium of canada } \\
\text { enthesitis Index }\end{array}$ & $\begin{array}{l}\text { Maastricht ankylosing } \\
\text { spondylitis enthesitis score }\end{array}$ & $\begin{array}{l}\text { Leeds enthesitis } \\
\text { index }\end{array}$ & $\begin{array}{l}\text { Major enthesitis } \\
\text { index }\end{array}$ \\
\hline Total no of sites & 14 & 13 & 6 & 12 \\
\hline $\begin{array}{l}\text { Supraspinatus insertion at greater } \\
\text { tuberosity of humerus }\end{array}$ & $x$ & & & \\
\hline $\begin{array}{l}\text { Common flexor insertion at medial } \\
\text { epicondyle of humerus }\end{array}$ & $x$ & & & $x$ \\
\hline $\begin{array}{l}\text { Common extensor insertion at lateral } \\
\text { epicondyle of humerus }\end{array}$ & $x$ & & $x$ & $x$ \\
\hline Ist costochondral joint & & $x$ & & \\
\hline 7th costochondral joint & & $x$ & & \\
\hline $\begin{array}{l}\text { Hip extensor insertion at greater } \\
\text { trochanter of femur }\end{array}$ & & & & $x$ \\
\hline $\begin{array}{l}\text { Quadriceps insertion at superior } \\
\text { border of patella }\end{array}$ & $x$ & & & \\
\hline $\begin{array}{l}\text { Patellar ligament insertion at inferior } \\
\text { pole of patella }\end{array}$ & $x$ & & & \\
\hline Achilles tendon insertion at calcaneus & $x$ & $x$ & $x$ & $x$ \\
\hline Plantar fascia insertion at calcaneus & $x$ & & & $x$ \\
\hline Posterior superior iliac spine & & $x$ & & \\
\hline $\begin{array}{l}\text { Sartorius insertion at anterior } \\
\text { superior iliac spine }\end{array}$ & & $x$ & & \\
\hline Iliac crest & & $x$ & & $x$ \\
\hline 5th lumbar spinous process & & $x$ & & \\
\hline Medial femoral condyle & & & $x$ & \\
\hline
\end{tabular}

Sacroiliitis is defined by more stringent criteria in adults than in children. In adult studies, the positive and negative predictive values of physical examination to detect sacroiliitis are poor. ${ }^{33,34}$ As such, the European Spondyloarthropathy Study Group and Assessment in SpondyloArthritis International Society classification criteria and Amor criteria for axial $\mathrm{SpA}$ in adults require the diagnosis of sacroiliitis to be made by imaging with radiographs or MRI. In adults, the gold standard for the early diagnosis of sacroiliitis is MRI with Short TI Inversion Recovery. ${ }^{35-37}$ Typical findings of sacroiliitis on MRI include bone marrow edema within the sacrum and/or adjacent ilium with or without capsulitis (inflammation of the joint capsule) or enthesitis. ${ }^{35}$ USD has been proposed as an alternative and less expensive method to evaluate sacroiliitis in adults. ${ }^{38-40}$ USD is operator-dependent, however, and lacks sufficient resolution and penetration depth to adequately and reliably visualize the sacroiliac joints. ${ }^{41}$ Whole-body MRI has also been proposed as an alternative method to evaluate the axial skeleton in adults with early disease. ${ }^{42,43}$ In adults with early inflammatory back pain, $24 \%$ and $22 \%$ had both lumbar and sacroiliac joint lesions or lumbar spinal lesions only, respectively, which were detectable by whole-body MRI. ${ }^{44}$ In children, preliminary studies have shown that changes in lumbosacral spine are less frequent and occur later in the disease course than sacroiliitis. ${ }^{45}$

\section{Treatment of ERA}

Treatment regimens for ERA, many of them based on adults with rheumatoid arthritis and ankylosing spondylitis, include monotherapy or combination therapy with NSAIDs, DMARDs, or biologic agents. NSAID monotherapy may be appropriate for children with low disease activity and without features of poor prognosis (Table 2). However, continuation of NSAID monotherapy for longer than 2 months for children with active arthritis is considered inappropriate. ${ }^{46}$ Many rheumatologists prefer indomethacin for patients with prominent enthesitis, or other agents in the indolacetic acid group such as diclofenac, sulindac, or tolectin. Some of these agents are not Food and Drug Administration approved for children (see Table 3 for medication specifics and Food and Drug Administration approval). NSAIDs can be safely used for months as long as laboratory studies are done routinely to monitor for hepatic and renal toxicity $(\mathrm{CBC}$, creatinine, liver function tests [LFTs], and urinalysis several weeks after initiation and then every 6-12 months).

Methotrexate (MTX) is one of the most commonly used DMARDs in JIA. The efficacy and safety of MTX have been established in JIA. ${ }^{47,48}$ MTX is recommended as initial treatment for children with oligo- and polyarticular disease, depending upon disease activity and features of 
Table 2 American College of Rheumatology juvenile idiopathic arthritis treatment guideline features of poor prognosis and disease activity levels ${ }^{46}$

\begin{tabular}{|c|c|c|c|}
\hline & Oligoarticular onset & Polyarticular onset & Active sacroiliitis \\
\hline $\begin{array}{l}\text { Features of poor } \\
\text { prognosis }\end{array}$ & $\begin{array}{l}\text { - Arthritis of hip or cervical spine } \\
\text { - Arthritis of the ankle or wrist and } \\
\text { marker or prolonged elevation of } \\
\text { inflammatory markers } \\
\text { - Radiographic joint damage }\end{array}$ & $\begin{array}{l}\text { - Arthritis of hip or cervical spine } \\
\text { - Positive RF or anticyclic citrullinated } \\
\text { peptide antibodies } \\
\text { - Radiographic joint damage }\end{array}$ & - Radiographic joint damage \\
\hline \multicolumn{4}{|c|}{ Disease activity levels } \\
\hline Low & $\begin{array}{l}\text { - } \leq \mathrm{I} \text { active joint } \\
\text { - Normal ESR or CRP } \\
\text { - PGA }<3 \\
\text { - Parent global assessment of } \\
\text { overall well-being }<2\end{array}$ & $\begin{array}{l}\text { - } \leq 4 \text { active joints } \\
\text { - Normal ESR or CRP } \\
\text { - PGA }<3 \\
\text { - Parent global assessment of overall } \\
\text { well-being }<2\end{array}$ & $\begin{array}{l}\text { - Normal back flexion } \\
\text { - Normal ESR or CRP } \\
\text { - PGA }<3 \\
\text { - Parent global assessment of overall } \\
\text { well-being }<2\end{array}$ \\
\hline Moderate & $\begin{array}{l}-\geq \text { I features greater than low } \\
\text { disease activity and }<3 \text { features } \\
\text { of high disease activity }\end{array}$ & $\begin{array}{l}\text { - } \geq \text { I features greater than low disease } \\
\text { activity and }<3 \text { features of high } \\
\text { disease activity }\end{array}$ & $\begin{array}{l}\text { - } \geq \text { I features greater than low disease } \\
\text { activity and }<2 \text { features of high } \\
\text { disease activity }\end{array}$ \\
\hline High & $\begin{array}{l}\text { - } \geq 2 \text { active joints } \\
\text { - } E S R \text { of } C R P \text { greater than } 2 \times \text { normal } \\
\text { - } P G A \geq 7 \\
\text { - Parent global assessment of overall } \\
\text { well-being } \geq 4\end{array}$ & $\begin{array}{l}\text { - } \geq 8 \text { active joints } \\
\text { - } \text { ESR of } C R P \text { greater than } 2 \times \text { normal } \\
\text { - } \text { PGA } \geq 7 \\
\text { - Parent global assessment of overall } \\
\text { well-being } \geq 5\end{array}$ & $\begin{array}{l}\text { - } E S R \text { of } C R P \text { greater than } 2 \times \text { normal } \\
\text { - } P G A \geq 7 \\
\text { - Parent global assessment of overall } \\
\text { well-being } \geq 4\end{array}$ \\
\hline
\end{tabular}

Abbreviations: CRP, C-reactive protein; ESR, erythrocyte sedimentation rate; PGA, physician global assessment; RF, rheumatoid factor.

poor prognosis ${ }^{46}$ MTX is a folic acid analog, a competitive inhibitor of dihydrofolate reductase, and modulates the effect of inflammatory cells and cytokines. The typical dose is $10-15 \mathrm{mg} / \mathrm{m}^{2}$ per week orally or subcutaneously. ${ }^{49,50} \mathrm{At}$ doses greater than $10 \mathrm{mg} / \mathrm{m}^{2}$ per week, the bioavailability and side effect profile of subcutaneous MTX is better than oral. ${ }^{51}$ MTX typically takes 6-8 weeks before clinical benefit is achieved. Side effects include nausea, vomiting, abdominal pain, oral ulcerations, hepatotoxicity, and cytopenias. The recent American College of Rheumatology guidelines recommend checking $\mathrm{CBC}$, LFTs, and creatinine prior to initiation, approximately 1 month after initiation, and then every 3-4 months thereafter if prior results are normal and the dose is stable. ${ }^{46}$ Although MTX is effective for arthritis, its efficacy for enthesitis, sacroiliitis, and inhibition of structural damage has not been assessed in children with ERA.

Sulfasalazine (SSZ) is another frequently used DMARD in JIA. In one open-label multicenter study, children with
HLA-B27-positive oligoarthritis responded well to 1 year of therapy. ${ }^{52}$ In another 26-week randomized, double-blind, placebo-controlled study of juvenile SpA, there was no significant difference between SSZ and placebo in active joint count, tender entheses count, pain visual analog scale, or spinal flexion. However, subjects who received SSZ had a significant improvement in the physician and patient assessments of overall improvement. ${ }^{53} \mathrm{SSZ}$ is an analog of 5-aminosalicylic acid linked to sulfapyridine; therefore, it has some inflammatory and antimicrobial properties. Like MTX, SSZ is recommended following a trial of NSAIDs for ERA patients with moderate or high disease activity. ${ }^{46} \mathrm{~A}$ typical dose is $30-50 \mathrm{mg} / \mathrm{kg}$ per day orally. The dose is titrated over several weeks, and clinical improvement is expected 6-8 weeks after initiation. Side effects include gastrointestinal upset, cytopenias, hepatotoxicity, hypogammaglobulinemia, and Stevens-Johnson syndrome. It is recommended to check CBC, LFTs, and creatinine prior to initiation, approximately

Table 3 Nonsteroidal anti-inflammatory drugs for enthesitis-related arthritis treatment

\begin{tabular}{|c|c|c|c|c|}
\hline Medication & Dose & $\begin{array}{l}\text { Maximum daily } \\
\text { dose }\end{array}$ & $\begin{array}{l}\text { Food and drug } \\
\text { administration approved }\end{array}$ & $\begin{array}{l}\text { Liquid formulation } \\
\text { available }\end{array}$ \\
\hline Diclofenac & $2-3 \mathrm{mg} / \mathrm{kg} /$ day, divided twice daily & $150 \mathrm{mg}$ & No & No \\
\hline Indomethacin & $2-4 \mathrm{mg} / \mathrm{kg} /$ day, divided three times a day & $200 \mathrm{mg}$ & Yes & Yes \\
\hline Meloxicam & $0.25 \mathrm{mg} / \mathrm{kg} /$ day, daily & $15 \mathrm{mg}$ & Yes & Yes \\
\hline Naproxen & $20 \mathrm{mg} / \mathrm{kg} /$ day, divided twice daily & $1000 \mathrm{mg}$ & Yes & Yes \\
\hline Sulindac & 4-6 mg/kg/day, divided twice daily & $400 \mathrm{mg}$ & No & No \\
\hline Tolmetin & $20-30 \mathrm{mg} / \mathrm{kg} / \mathrm{day}$, divided three or four times a day & $1800 \mathrm{mg}$ & Yes & No \\
\hline
\end{tabular}


1 month after initiation, and then every 3-4 months thereafter if prior results are normal and the dose is stable.

Biologic agents currently approved for the treatment of the nonsystemic forms of JIA are abatacept and the antitumor necrosis factor (TNF) agents etanercept and adalimumab. Anti-TNF agents have established efficacy in adults for arthritis, enthesitis, and spinal disease. Analyses from an observational pediatric registry demonstrated that anti-TNF agents were effective and safe in patients with ERA who were previously unresponsive to one or more DMARDs. ${ }^{54}$ However, sustained remission on medication was difficult, and no one achieved remission off medication. ${ }^{54}$ In another retrospective case series of ten juvenile SpA patients, antiTNF therapy was effective for both enthesitis and synovitis. ${ }^{55}$ The typical dose for etanercept is $0.8 \mathrm{mg} / \mathrm{kg}$ subcutaneously per week (maximum $50 \mathrm{mg}$ ). The typical adalimumab dose is $20 \mathrm{mg}$ or $40 \mathrm{mg}$ subcutaneously every other week for weight less than or greater than $30 \mathrm{~kg}$, respectively. Testing for latent tuberculosis must be performed prior to initiating anti-TNF therapy and yearly thereafter. Side effects of antiTNFs include risk of infection, cytopenias, hypersensitivity reaction, psoriasis, demyelination, and malignancy.

Anti-TNF agents are effective in adults with early axial inflammation that is detectable by MRI but not by radiographs. ${ }^{56}$ Once sacroiliitis has developed and damage is detectable on radiographs, DMARDs and anti-TNF agents may help symptomatically, but they do not inhibit progression of axial structural damage. ${ }^{57-60}$

\section{Prognosis}

Observational studies suggest that ongoing disease activity in ERA for more than 5 years predicts disability. ${ }^{61}$ Tarsitis, HLA-B27 positivity, hip arthritis within the first 6 months, and disease onset after age 8 years are associated with disease progression. ${ }^{32,62}$ In comparison with other JIA categories, ERA is associated with worse function, quality of life, and pain, ${ }^{63}$ as well as a smaller likelihood of attaining inactive disease 1 year after treatment initiation. ${ }^{64}$ Disease remission occurs in less than $20 \%$ of children with ERA 5 years after diagnosis. ${ }^{61}$

As our understanding of the pathophysiology of ERA, enthesitis, and sacroiliitis improves and with the advent of additional biologic therapies, the prognosis of children and adolescents with ERA will likely improve.

\section{Acknowledgment}

The author thanks Dr David Sherry for his critical review of this manuscript.

\section{Disclosure}

The author reports no conflicts of interest in this work.

\section{References}

1. Karvonen M, Viik-Kajander M, Moltchanova E, Libman I, LaPorte R, Tuomilehto J. Incidence of childhood type 1 diabetes worldwide. Diabetes Mondiale (DiaMond) Project Group. Diabetes Care. 2000; 23(10):1516-1526.

2. Solau-Gervais E, Robin C, Gambert C, et al. Prevalence and distribution of juvenile idiopathic arthritis in a region of Western France. Joint Bone Spine. 2010;77(1):47-49.

3. Oen K, Tucker L, Huber AM, et al. Predictors of early inactive disease in a juvenile idiopathic arthritis cohort: results of a Canadian multicenter, prospective inception cohort study. Arthritis Rheum. 2009;61(8): 1077-1086.

4. Yilmaz M, Kendirli SG, Altintas DU, Karakoc GB, Inal A, Kilic M. Juvenile idiopathic arthritis profile in Turkish children. Pediatr Int. 2008;50(2):154-158.

5. Saurenmann RK, Rose JB, Tyrrell P, et al. Epidemiology of juvenile idiopathic arthritis in a multiethnic cohort: ethnicity as a risk factor. Arthritis Rheum. 2007;56(6):1974-1984.

6. Weiss PF, Klink AJ, Behrens EM, et al. Enthesitis in an inception cohort of enthesitis-related arthritis. Arthritis Care Res (Hoboken). 2011;63(9):1307.

7. Petty RE, Southwood TR, Manners P, et al. International League of Associations for Rheumatology classification of juvenile idiopathic arthritis: second revision, Edmonton, 2001. J Rheumatol. 2004;31(2): 390-392.

8. Cassidy JT, Petty R, Laxer RM, Lindsley C. Textbook of pediatric rheumatology. 6th ed. Philadelphia, PA: Elvesier; 2011.

9. Burgos-Vargas R, Clark P. Axial involvement in the seronegative enthesopathy and arthropathy syndrome and its progression to ankylosing spondylitis. J Rheumatol. 1989;16(2):192-197.

10. Flato B, Hoffmann-Vold AM, Reiff A, Forre O, Lien G, Vinje O. Long-term outcome and prognostic factors in enthesitis-related arthritis: a case-control study. Arthritis Rheum. 2006;54(11):3573-3582.

11. Weiss PF, Klink AJ, Behrens EM, et al. Prevalence of enthesitis in pediatric patients with Enthesitis-Related Arthritis Arthritis Rheum. 2010;62(10):S98-S99.

12. Rachlis A, Babyn P, Lobo-Mueller E, et al. Whole body magnetic resonance imaging in juvenile spondyloarthritis: will it provide vital information compared to clinical exam alone? Arthritis Rheum. 2011;63(10):S292.

13. Resnick D, Niwayama G. Entheses and enthesopathy. Anatomical, pathological, and radiological correlation. Radiology. 1983;146(1):1-9.

14. Resnick D, Feingold ML, Curd J, Niwayama G, Goergen TG. Calcaneal abnormalities in articular disorders. Rheumatoid arthritis, ankylosing spondylitis, psoriatic arthritis, and Reiter syndrome. Radiology. 1977; 125(2):355-366.

15. Nebenzahl II, Ron A, Rostoker N. Nebenzahl, Ron, and Rostoker reply. Phys Rev Lett. 1989;62(25):3012.

16. Ansell B. Juvenile spondylitis and related disorders. Ankylosing Spondylitis. Moll J, editor. Edinburgh, UK: Churchill Livingstone; 1980.

17. Sherry DD, Sapp LR. Enthesalgia in childhood: site-specific tenderness in healthy subjects and in patients with seronegative enthesopathic arthropathy. $J$ Rheumatol. 2003;30(6):1335-1340.

18. Mander M, Simpson JM, McLellan A, Walker D, Goodacre JA, Dick WC. Studies with an enthesis index as a method of clinical assessment in ankylosing spondylitis. Ann Rheum Dis. 1987;46(3):197-202.

19. Gorman JD, Sack KE, Davis JC Jr. Treatment of ankylosing spondylitis by inhibition of tumor necrosis factor alpha. N Engl J Med. 2002;346(18):1349-1356.

20. Maksymowych WP, Mallon C, Morrow S, et al. Development and validation of the Spondyloarthritis Research Consortium of Canada (SPARCC) Enthesitis Index. Ann Rheum Dis. 2009;68(6):948-953. 
21. Heuft-Dorenbosch L, Spoorenberg A, van Tubergen A, et al. Assessment of enthesitis in ankylosing spondylitis. Ann Rheum Dis. 2003;62(2): 127-132.

22. Gladman DD, Inman RD, Cook RJ, et al. International spondyloarthritis interobserver reliability exercise - the INSPIRE study: II. Assessment of peripheral joints, enthesitis, and dactylitis. J Rheumatol. 2007;34(8): 1740-1745.

23. Braun J, Brandt J, Listing J, et al. Treatment of active ankylosing spondylitis with infliximab: a randomised controlled multicentre trial. Lancet. 2002;359(9313):1187-1193.

24. D'Agostino MA, Said-Nahal R, Hacquard-Bouder C, Brasseur JL, Dougados M, Breban M. Assessment of peripheral enthesitis in the spondylarthropathies by ultrasonography combined with power Doppler: a cross-sectional study. Arthritis Rheum. 2003;48(2): 523-533.

25. Sprott H, Jeschonneck M, Grohmann G, Hein G. Microcirculatory changes over the tender points in fibromyalgia patients after acupuncture therapy (measured with laser-Doppler flowmetry). Wien Klin Wochenschr. 2000;112(13):580-586.

26. D’Agostino MA, Breban M, Brasseur JL, Canale M, Magaro M. Ultrasonographic (US) assessment of spondyloarthropathy ( $\mathrm{SpA}$ ) enthesitis, displays vascularization change specific of inflammatory process abstract. Arthritis Rheum. 2001;44 Suppl 9:S95.

27. Spadaro A, Iagnocco A, Perrotta FM, Modesti M, Scarno A, Valesini G. Clinical and ultrasonography assessment of peripheral enthesitis in ankylosing spondylitis. Rheumatology. 2011;50(11):2080-2086.

28. Jousse-Joulin S, Breton S, Cangemi C, et al. Ultrasonography for detecting enthesitis in juvenile idiopathic arthritis. Arthritis Care Res (Hoboken). 2011;63(6):849-855.

29. Kiris A, Kaya A, Ozgocmen S, Kocakoc E. Assessment of enthesitis in ankylosing spondylitis by power Doppler ultrasonography. Skeletal Radiol. 2006;35(7):522-528.

30. Rudwaleit M, van der Heijde D, Landewe R, et al. The development of Assessment of SpondyloArthritis International Society classification criteria for axial spondyloarthritis (part II): validation and final selection. Ann Rheum Dis. 2009;68(6):777-783.

31. Rudwaleit M, Metter A, Listing J, Sieper J, Braun J. Inflammatory back pain in ankylosing spondylitis: a reassessment of the clinical history for application as classification and diagnostic criteria. Arthritis Rheum. 2006;54(2):569-578.

32. Stoll ML, Bhore R, Dempsey-Robertson M, Punaro M. Spondyloarthritis in a pediatric population: risk factors for sacroiliitis. J Rheumatol. 2010;37(11):2402-2408

33. Spadaro A, Iagnocco A, Baccano G, Ceccarelli F, Sabatini E, Valesini G. Sonographic-detected joint effusion compared with physical examination in the assessment of sacroiliac joints in spondyloarthritis. Ann Rheum Dis. 2009;68(10):1559-1563.

34. Williamson L, Dockerty JL, Dalbeth N, McNally E, Ostlere S, Wordsworth BP. Clinical assessment of sacroiliitis and HLA-B27 are poor predictors of sacroiliitis diagnosed by magnetic resonance imaging in psoriatic arthritis. Rheumatology (Oxford). 2004;43(1):85-88.

35. Sieper J, Rudwaleit M, Baraliakos X, et al. The Assessment of SpondyloArthritis International Society (ASAS) handbook: a guide to assess spondyloarthritis. Ann Rheum Dis. 2009;68 Suppl 2:ii1-44.

36. Tuite MJ. Sacroiliac joint imaging. Semin Musculoskelet Radiol. 2008;12(1):72-82.

37. Puhakka KB, Jurik AG, Egund N, et al. Imaging of sacroiliitis in early seronegative spondylarthropathy. Assessment of abnormalities by MR in comparison with radiography and CT. Acta Radiol. 2003;44(2): 218-229.

38. Unlu E, Pamuk ON, Cakir N. Color and duplex Doppler sonography to detect sacroiliitis and spinal inflammation in ankylosing spondylitis. Can this method reveal response to anti-tumor necrosis factor therapy? J Rheumatol. 2007;34(1):110-116.

39. Arslan H, Sakarya ME, Adak B, Unal O, Sayarlioglu M. Duplex and color Doppler sonographic findings in active sacroiliitis. AJR. 1999;173(3):677-680.
40. Klauser A, Halpern EJ, Frauscher F, et al. Inflammatory low back pain: high negative predictive value of contrast-enhanced color Doppler ultrasound in the detection of inflamed sacroiliac joints. Arthritis Rheum. 2005;53(3):440-444.

41. Sturrock RD. Clinical utility of ultrasonography in spondyloarthropathies. Curr Rheumatol Rep. 2009;11(5):317-320.

42. Weber U, Hodler J, Jurik AG, et al. Assessment of active spinal inflammatory changes in patients with axial spondyloarthritis: validation of whole body MRI against conventional MRI. Ann Rheum Dis. 2010;69(4):648-653.

43. Bennett AN, Marzo-Ortega H, Rehman A, Emery P, McGonagle D. The evidence for whole-spine MRI in the assessment of axial spondyloarthropathy. Rheumatology. 2010;49(3):426-432.

44. Marzo-Ortega H, McGonagle D, O’Connor P, et al. Baseline and 1 -year magnetic resonance imaging of the sacroiliac joint and lumbar spine in very early inflammatory back pain. Relationship between symptoms, HLA-B27 and disease extent and persistence. Ann Rheum Dis. 2009;68(11):1721-1727.

45. Brophy S, Mackay K, Al-Saidi A, Taylor G, Calin A. The natural history of ankylosing spondylitis as defined by radiological progression. J Rheumatol. 2002;29(6):1236-1243.

46. Beukelman T, Patkar NM, Saag KG, et al. 2011 American College of Rheumatology recommendations for the treatment of juvenile idiopathic arthritis: initiation and safety monitoring of therapeutic agents for the treatment of arthritis and systemic features. Arthritis Care Res (Hoboken). 2011;63(4):465-482.

47. Woo P, Southwood TR, Prieur AM, et al. Randomized, placebocontrolled, crossover trial of low-dose oral methotrexate in children with extended oligoarticular or systemic arthritis. Arthritis Rheum. 2000;43(8):1849-1857.

48. Giannini EH, Brewer EJ, Kuzmina N, et al. Methotrexate in resistant juvenile rheumatoid arthritis. Results of the USA-USSR double-blind, placebo-controlled trial. The Pediatric Rheumatology Collaborative Study Group and The Cooperative Children's Study Group. $N$ Engl J Med. 1992;326(16):1043-1049.

49. Wallace CA, Giannini EH, Spalding SJ, et al; for the Childhood Arthritis Rheumatology Research Alliance (CARRA). Trial of early aggressive therapy in polyarticular juvenile idiopathic arthritis. Arthritis Rheum. 2011 December 19. [Epub ahead of print.]

50. Tynjala P, Vahasalo P, Tarkiainen M, et al. Aggressive combination drug therapy in very early polyarticular juvenile idiopathic arthritis (ACUTE-JIA): a multicentre randomised open-label clinical trial. Ann Rheum Dis. 2011;70(9):1605-1612.

51. Tukova J, Chladek J, Nemcova D, Chladkova J, Dolezalova P. Methotrexate bioavailability after oral and subcutaneous dministration in children with juvenile idiopathic arthritis. Clin Exp Rheumatol. 2009;27(6):1047-1053.

52. Ansell B, Hall M, Loftus J. A multicenter pilot study of sulphasalazine in juvenile chronic arthritis. Clin Exp Rheumatol. 1991;9:201.

53. Burgos-Vargas R, Vazquez-Mellado J, Pacheco-Tena C, HernandezGarduno A, Goycochea-Robles MV. A 26 week randomised, double blind, placebo controlled exploratory study of sulfasalazine in juvenile onset spondyloarthropathies. Ann Rheum Dis. 2002;61(10): 941-942.

54. Otten MH, Prince FH, Twilt M, et al. Tumor necrosis factor-blocking agents for children with enthesitis-related arthritis - data from the dutch arthritis and biologicals in children register, 1999-2010. J Rheumatol. 2011;38(10):2258-2263.

55. Tse SM, Burgos-Vargas R, Laxer RM. Anti-tumor necrosis factor alpha blockade in the treatment of juvenile spondylarthropathy. Arthritis Rheum. 2005;52(7):2103-2108.

56. Haibel H, Rudwaleit M, Listing J, et al. Efficacy of adalimumab in the treatment of axial spondylarthritis without radiographically defined sacroiliitis: results of a twelve-week randomized, double-blind, placebo-controlled trial followed by an open-label extension up to week fifty-two. Arthritis Rheum. 2008;58(7):1981-1991. 
57. Haibel H, Brandt HC, Song IH, et al. No efficacy of subcutaneous methotrexate in active ankylosing spondylitis: a 16-week open-label trial. Ann Rheum Dis. 2007;66(3):419-421.

58. van der Heijde D, Landewe R, Baraliakos X, et al. Radiographic findings following two years of infliximab therapy in patients with ankylosing spondylitis. Arthritis Rheum. 2008;58(10):3063-3070.

59. van der Heijde D, Salonen D, Weissman BN, et al. Assessment of radiographic progression in the spines of patients with ankylosing spondylitis treated with adalimumab for up to 2 years. Arthritis Res Ther. 2009;11(4):R127.

60. van der Heijde D, Landewe R, Einstein S, et al. Radiographic progression of ankylosing spondylitis after up to two years of treatment with etanercept. Arthritis Rheum. 2008;58(5):1324-1331.

61. Flato B, Aasland A, Vinje O, Forre O. Outcome and predictive factors in juvenile rheumatoid arthritis and juvenile spondyloarthropathy. J Rheumatol. 1998;25(2):366-375.
62. Flato B, Smerdel A, Johnston V, et al. The influence of patient characteristics, disease variables, and HLA alleles on the development of radiographically evident sacroiliitis in juvenile idiopathic arthritis. Arthritis Rheum. 2002;46(4):986-994.

63. Weiss PF, Beukelman P, Schanberg T, Kimura LE, Colbert Y, Investigators RA. Enthesitis is a significant predictor of decreased quality of life, function, and arthritis-specific pain across juvenile arthritis (JIA) categories: preliminary analyses from the CARRAnet Registry. Arthritis Rheum. 2011;62(10):S105.

64. Donnithorne KJ, Cron RQ, Beukelman T. Attainment of inactive disease status following initiation of TNF-alpha inhibitor therapy for juvenile idiopathic arthritis: enthesitis-related arthritis predicts persistent active disease. J Rheumatol. 2011;38(12):2675-2681.

\section{Publish your work in this journal}

Adolescent Health, Medicine and Therapeutics is an international, peer-reviewed, open access journal focusing on health, pathology, and treatment issues specific to the adolescent age group. All aspects of health maintenance, preventative measures and disease treatment interventions are addressed within the journal and practitioners from all disciplines are invited to submit their work as well as healthcare researchers and patient support groups.. The manuscript management system is completely online and includes a very quick and fair peerreview system. Visit http://www.dovepress.com/testimonials.php to read real quotes from published authors.

Submit your manuscript here: http://www.dovepress.com/adolescent-health-medicine-and-therapeutics-journal 